\title{
A Pilot Study of Quantifying Turkey's Foreign Affairs: Data Generation, Challenges, and Preliminary Analysis
}

\author{
Musa Tüzüner \\ Center for Foreign Policy and Peace Research \\ Gonca Biltekin \\ Bilkent University
}

\begin{abstract}
This paper provides a simple introduction to event data analysis, a quantitative data collection and analysis approach that has been used extensively for compiling broad datasets of foreign policy and other international behaviors. The authors define the steps undertaken in creating the Turkish Foreign Affairs Event Dataset (TFAED). This pilot study, which uses a single news source and covers a 23-year period (1990-2013) of foreign affairs in Turkey, was completed to evaluate the feasibility, time, cost, and possible problems that might be encountered with a full-scope study. The paper describes the obstacles encountered during the pilot study's initial phases and discusses a sample of the preliminary findings. The paper concludes with potential uses of the dataset.
\end{abstract}

Keywords: Turkish foreign policy, Event data, Turkish foreign affairs, Quantitative methods

\section{Introduction}

In recent years, there has been growing debate about the nature of the evolution of Turkish foreign policy and whether it constitutes dramatic new changes. Despite numerous research inquiries, primarily of a qualitative nature, there remain few firm, consensus-based answers to pivotal questions about Turkish foreign policy, such as its current ideological and physical direction, the nature and type of its main actors, and its primary motivations. Such questions may be addressed by examining Turkish foreign policy and its presumed newness with methods and tools (including previously neglected quantitative ones) that would enable us to look at the subject matter in a more longitudinal and holistic manner and provide opportunities for broad comparative analyses. The idea for creating the Turkish Foreign Affairs Event Dataset (TFAED) by using event data analysis arose out of such observations and concerns.

The TFAED project employs event data analysis to build up a 23-year dataset (19912012) of Turkish foreign affairs. Using this dataset, the project will then hypothesize on various primary inquiries about the subject matter, for example, the axis-shift debate, the zero-problems-with-neighbours policy, the role of non-state actors in Turkey's foreign affairs, and Turkish-Israeli relations. By focusing on these issues and many more, the project is hoping to identify new behavioral patterns, emerging new actors, and the dynamics of new directional tendencies in Turkish foreign policy. With further analyses of such characteristics,

* Musa Tüzüner, PhD, Research Fellow, Center for Foreign Policy and Peace Research. Email: mtuzuner@kent.edu. Gonca Biltekin, PhD Candidate, Bilkent University. Email: goncabi@bilkent.edu.tr. 
it also seeks to identify possible structural elements in Turkish foreign policy that can be utilized for homegrown conceptualization efforts.

In the following sections, we provide a simple introduction to gathering event data and define the steps already undertaken in building TFAED. We completed a pilot study that uses a single news source to evaluate the feasibility, time, cost, and possible problems that might be encountered in a full-scope study. In the second part, we discuss the obstacles encountered during the initial phases. We then provide a sample of the preliminary findings that arose out of this pilot study.

\section{Building TFAED}

Event-data research has a long history in several academic disciplines, ${ }^{1}$ and has been used extensively in international relations research. The approach first saw a rapid growth in the 1960s and 1970s, with pioneering projects such as the World Event/Interaction Survey (WEIS) ${ }^{2}$ and the creation of the Conflict and Peace Data Bank (COPDAB). ${ }^{3}$ Both of these efforts aggregated individual events by converting them into a measure of cooperation or conflict.

With the introduction of machine-coding programs in the 1990s, the time and workforce needed for comprehensive datasets have been significantly reduced. The earliest such software program was the Kansas Event Data System (KEDS), ${ }^{4}$ which helped spawn Text Analysis by Augmenting Replacement Instructions (TABARI) ${ }^{5}$, VRA-Reader, and Java-based Text Analysis by Augmenting Replacement Instructions (JABARI). ${ }^{6}$ All of these programs provide relatively easy ways of extracting data from international wire news sources by coding the lead sentences in press releases.

Past major event-data projects on political or security issues have covered a wide range of events, from those at the global level (e.g., COPDAB, WEIS, Integrated Data for Event Analysis (IDEA) ${ }^{7}$, Protocol for the Analysis of Nonviolent Direct Action (PANDA), ${ }^{8}$ and the more-recent Global Data on Events, Location and Tone (GDELT) $)^{9}$ to those focused on particular regions (e.g., the Intranational Political Interactions (IPI) Project ${ }^{10}$ and the

\footnotetext{
A long tradition of such research exists in history and sociology, with the latter including a particularly rich literature on collective action and social movements (reviewed in R. Franzosi, "The Press as a Source of Sociohistorical Data," Historical Methods 20, no. 1 (1987): 5-16; D. Rucht, R. Koopmans, F. Neidhardt, eds., Acts of Dissent (New York: Rowman \& Littlefield, 1999); S. Olzak, "Analysis of Events in Studies of Collective Actions," Annual Review of Sociology 15 (1989): 119-141.

Charles A. McClelland, World Event/Interaction Survey (WEIS) 1966-1978 (ICPSR5211) (Ann Arbor, Michigan: InterUniversity Consortium for Political and Social Research, 1978).

Edward E. Azar, "The Conflict and Peace Data Bank (COPDAB) Project," The Journal of Conflict Resolution 24, no. 1 (1980): 143-152.

Philip A. Schrodt, Shannon G. Davis, and Judy L. Weddle, "Political Science: KEDS - A Program for the Machine Coding of Event Data," Social Science Computer Review 12, no. 3 (1994): 561-588.

Phillip A. Schrodt, TABARI Textual Analysis by Augmented Replacement Instructions Version 0.8.4 Manual available at http://eventdata.psu.edu/tabari.dir/tabari.manual.0.8.4b1.pdf.

6 See Virtual Reserach Associates' website (http://vranet.com/ for more information on VRA-Reader). JABARI, a proprietary work of the Lockheed Martin Advanced Technology Laboratories, is based on TABARI. See Philip A. Schrodt and David Van Brackle, "Automated Coding of Political Event Data" in Handbook of Computational Approaches to Counterterrorism, ed. V.S. Subrahmanian, 2013, 23-49, Springer Science and Business Media, NY.

Doug Bond et al., "Integrated Data for Events Analysis (IDEA): An Event Typology for Automated Events Data Development," Journal of Peace Research 40, no. 6 (2003): 733-745.

Doug Bond and Joe Bond, 1995. Panda Codebook. Cambridge, MA: The Program on Nonviolent Sanctions and Cultural Survival, Weatherhead Center for International Affairs, Harvard University.

9 Kalev Leetaru and Philip A. Schrodt "GDELT: Global Data on Events, Location and Tone, 1979-2012” (paper presented at the annual International Studies Association convention, San Francisco, April 3-6, 2013).

10 David R. Davis, Brett Ashley Leeds, and Will H. Moore, "Measuring Dissident and State Behaviour: The Intranational Political Interactions (IPI) Project" (paper presented at the Workshop on Cross-National Data Collection, Texas A\&M University, 
European Protest and Coercion dataset). ${ }^{11}$ Other datasets have been created to cover morefocused types of events, such as global terrorism (e.g., the International Terrorism: Attributes of Terrorist Events dataset (ITERATE) ${ }^{12}$ and the Terrorism Knowledge Base (TKB)) ${ }^{13}$ as well as domestic or regional terrorism (e.g., the Terrorism in Western Europe dataset (TWEED) ${ }^{14}$ and PCSTERROR (Project Civil Strife-Terror)). ${ }^{15}$

When we look at event-data studies in general, we observe that some event data concerning Turkey has been gathered (see the KEDS ${ }^{16}$ and VRA websites), usually as part of regionspecific studies that generally focus on conflicts. For example, when the KEDS project gathered data about conflicts in the Balkans, data about Turkey's Kurdish conflict were also coded. As part of the same project, a dataset about Turkey was established ${ }^{17}$ focusing on conflicts between domestic actors. ${ }^{18}$

Event-data studies at Harvard University have also been dominated by a focus on conflict; a study profiling conflict zones around the world used data about Turkey, Afghanistan, and Libya. ${ }^{19}$

While the above datasets provide some information, there is no event dataset specifically designed for understanding Turkey's foreign relations, neither in Turkey nor abroad.

\subsection{Preparations}

Once Aydınlı and Tüzüner's idea of quantifying Turkish foreign policy behavior evolved into a project to build a dataset, the first thing to do was to recruit research assistants and assemble the work team. This task was the hardest part of the project. We determined that we needed a team of three to four research assistants to begin the project. The project is expected to last three to four years, so we planned to gradually double the number of recruits, because over time, we expected that some would move on to other things such as relocating to a different city, acquiring a new job, studying abroad, etc.

Because there have been no similar studies in Turkish universities, research assistants interested in this study were hard to find. Most Turkish graduate students familiar with the event-data method (and there were few) had pursued their Master's degree abroad and worked under supervisors there. Because it would be difficult to work with students overseas, we

11 Ronald A. Francisco "The Relationship between Coercion and Protest: An Empirical Evaluation in Three Coercive States" The Journal of Conflict Resolution, Vol. 39, no. 2 (1995): 263-282. See http://www.nsd.uib.no/macrodataguide/set.html?id=52\&sub=1 for entire dataset. See also Llewellyn D. Howell and Gillian Barnes, "Event Data for Region-Specific Interactions: A Research Note on Source Coverage," in International Event-Data Developments: DDIR Phase II, eds. R. L. Merritt, R. G. Muncaster, and D. A. Zinnes (Ann Arbor: The University of Michigan Press, 1993), 45-54.

${ }_{12}$ See the ITERATE Webpage at Duke University: http://ibrary.duke.edu/data/collections/iterate.html.

13 Brian K. Houghton “Terrorism Knowledge Base: A Eulogy (2004-2008)" Perspectives on Terrorism 2, no. 7 (2008): 18-19.

${ }_{14}$ Jan Oskar Engene, "Five Decades of Terrorism in Europe: The TWEED Dataset," Journal of Peace Research 44, no. 1 (2007): 109-12

${ }^{15}$ S. M. Shellman, "Quantifying Violence and Nonviolence: Terrorism \& Political Violence Events Data Sets," Electronic Newsletter of the ECPR-SG on Extremism \& Democracy 9, no. 2 (2008), accessed August 19, 2011, http://www.tufts.edu/ dart01/ extremismanddemocracy/newsletter/Article7_4.html.

${ }^{16}$ See the Pennsylvania State University Event Data Project website at http://eventdata.psu.edu/index.html. The KEDS project moved to PSU in January 2010.

17 Ömür Y1lmaz, “Turkey Data Set,” accessed August 19, 2011, http://web.ku.edu/ keds/data.html. (The Turkey Data Set covers Turkey for the period January 3, 1992 to July 31, 2006 using the CAMEO coding scheme. It is based on Agence France Presse reports.)

18 Ömür Yılmaz, "The Kurdish Insurgency in Turkey: Pre- and Post-Ocalan" (paper presented at the annual meeting of the International Studies Association 48th Annual Convention, Chicago, 28 February 2007), accessed August 19, 2011, http:// www.allacademic.com/meta/p179221_index.html; Ömür Y1lmaz, "Turkish Military: the Key to Credible Commitment to Democracy" (paper presented at the annual meeting of the International Studies Association, San Diego, California, March 22, 2006), accessed August 19, 2011, http://www.allacademic.com/meta/p100868_index.html.

19 D. Bond and W. B. Vogele, "Profiles of International Hotspots" (unpublished manuscript, 1995), Center for International Affairs, Harvard University, accessed August 19, 2011, http://vranet.com/papers.html. 
wanted to find ones residing in Turkey. However, because creating datasets is not something most Turkish students are aware of, we had to show them what it entailed, and choose those who were truly interested. The first assistants were recruited through sharing this idea of building up a dataset on Turkey with other academics and grad students. It has been two years since we recruited the first two research assistants, and since then we have been able to recruit six more. Some have already begun project work, and the rest will soon follow.

Before building a dataset in the event-data method, the researcher should decide whether he or she will employ human coding or machine coding. For the purposes of this study, we used machine coding (Schrodt's free-access TABARI (Version 8.4b1)) because it is less costly and less time consuming than human coding.

The next task for the researcher is to decide on the news source for the raw/textual data. Previous event datasets have been generated using The New York Times (WEIS), Reuters (IDEA and KEDS), and Agence France Presse (AFP) (CAMEO-Levant Dataset). ${ }^{20}$ For two reasons, we decided to use AFP for this project. The first reason relates to some limitations that TABARI has: it can only parse English-language text and necessitates a certain format for text input, which can only be generated using additional formatting programs prior to coding. While the formatting programs are not complex, programming expertise is required to create them from scratch. Currently, free-access formatting programs for text by AFP are provided by Schrodt's team at Pennsylvania State University's Event Data Project Website (downloadable from the LexisNexis database (https://www.lexisnexis.com/hottopics/ lnacademic/)) and for text by Reuters from Factiva (http://global.factiva.com/sb/default. aspx?lnep=hp). However, several of our attempts to download Reuters news text from the Factiva database failed, probably due to Factiva's recent decision to provide .html links instead of the actual text. This situation rendered Reuters news text unavailable to us for reformatting and thus, for coding by TABARI.

The second reason we chose AFP was because trials with Reuters and AFP showed that AFP focuses more on political events and Reuters mainly reports events relevant to business and economics. ${ }^{21}$ For example, in the United States International Intelligence Behavior Dataset (USIIB) ${ }^{22}$ project, the authors compared reports on intelligence from Reuters and AFP between January 1, 2009 and December 31, 2009 and showed that AFP provided more news reports than Reuters, irrespective of the search term used.

We also considered using news reports from Anadolu Agency (AA), which is Turkey's official news agency. It provides English-language reports and it might have been efficient for extracting Turkey-related news, but no reformatting program exists for its reports. Moreover, although AA was established in the 1920 s, it only began posting online news reports in October 2009. In our contact with AA authorities, we found that there is an ongoing attempt to create online databases for all AA archives, but that has not yet been achieved. ${ }^{23}$ While we chose to use AFP for the pilot study, we will create reformatting programs for news reports from other sources, including AA, when we implement the full-scale project. Figure 1 shows the usual format of AFP news reports.

\footnotetext{
${ }^{20}$ For a full Levant dataset see the PSU Event Data Project at http://eventdata.psu.edu/data.dir/levant.html.

21 Philip A. Schrodt and Deborah J. Gerner, Analyzing International Event Data (2001/2012): 23-24, http://eventdata.psu.edu/ papers.dir/automated.html.

${ }_{22}$ Ersel Aydınlı and Musa Tuzuner, "Quantifying intelligence cooperation: The United States International Intelligence Behavior (USIIB) dataset” Journal of Peace Research 48, no. 5 (2011): 673-682.

${ }^{23}$ Hüseyin Köşger, Anadolu Agency Foreign News Assistant Editor, June 8, 2012.
} 


\section{4 of 2997 DOCUMENTS}

Agence France Presse -- English

August 25, 2011 Thursday 12:54 PM GMT

Turkey urges UN to urgently unfreeze Libyan assets

LENGTH: 111 words

DATELINE: ISTANBUL, Aug 252011

Turkish Foreign Minister Ahmet Davutoglu urged the United Nations Thursday to take action to unlock frozen Libyan assets.

Davutoglu made this statement at the start of a Libya Contact Group meeting of senior diplomats in Istanbul who are discussing the next steps for the country.

"We need to take action within the Security Council" to meet the needs of the National Transitional Council (NTC), he said, urging the international community to unlock frozen assets for the use of the Libyan people.

Davutoglu extended Turkey's full support to the NTC as the legitimate representative of the Libyan people and suggested its flag be hoisted at the UN headquarters in New York.

LOAD-DATE: August 26, 2011

LANGUAGE: ENGLISH

PUBLICATION-TYPE: Newswire

Copyright 2011 Agence France Presse

All Rights Reserved

Figure 1: AFP News Report, Unformatted

In the following section, we define the steps to build TFAED, which consist of developing actor lists and search terms to find relevant news reports, downloading relevant news and transforming it into machine-readable forms, and last, coding in terms of actors, events, and target actors according to pre-established standards.

\subsection{Developing actor lists}

To begin building the dataset, we needed to determine all state and non-state actors in Turkey. For this phase we had two assistants. One focused on government actors and the other on non-government actors. They determined which actors were active between 1999 and 2010 by studying websites of government organizations, newspapers, and official documents, and compiled a list of over 200 actors. The actor lists were then reassessed by three other assistants to improve methodological validity. At that point, we expanded the timespan from 1990 to 2012, to keep the dataset current. Compiling the actor lists took approximately two months. During that time, Turkey underwent government changes due to the June 2011 elections, which resulted in different people being assigned to certain positions, and several ministries being renamed and restructured. This situation necessitated updating some actor names.

\subsection{Developing key search terms}

Once the actors were determined, the next step was to establish key search terms that 
would enable us to find relevant news about the actors cited in AFP through the LexisNexis database. The two assistants were given brief training in the database and in developing key search terms. Next, they learned how to search the database and began to work intensively to find news about the actors they were responsible for. After four months of scanning the news between 1990 and 2012, the assistants had developed a list of key search terms for government and non-government actors.

The phrases used in news reports to denote an actor are usually different from that person's official title. For example, in the AFP reports for the Prime Minister of the Republic of Turkey, the following phrases (and more) are used: Turkish PM, Turkey's PM, Turkey PM, Turkish Premier, The Turkish and Iraqi premiers, Turkey's Poet Premier, Turkey's Prime Minister, Turkish Prime Minister. Moreover, there are recurrent spelling mistakes, such as Tukey's Prime Minister, Turkish Prime Mininster, and Turkey's Premiere. All phrases, including the typos, have been tagged to an actor.

\subsection{Downloading AFP news reports}

To determine the appropriate search terms, we made several inquiries in the LexisNexis Academic database through the different options available in its Advanced Search. For example, the term "Turk!" searches for all words that begin with "Turk" (without the exclamation point, only news items that mention "Turk" as a whole word would be returned, not, for example, "Turkish" or "Turkey"). When the news source is selected as "Agence France Presse," the section search determined as "LEAD," and the date specified as "between 1 Dec, 2012 to 31 Dec 2012," the query returns 458 news reports. These also include, however, news reports about the city of Turku in Finland, Turkana herdsmen in Kenya, Saudi Arabian writer Ahmed Turki, former Slovenian President Danilo Turk, the Turkmen people in Iraq, and Turkmenistan. While all these actors can be given a proper code in the TABARI coding process, downloading news reports irrelevant to a particular project should be avoided to conserve time and memory space. For the full-scale project, therefore, we will use separate search strings for each actor; but for the pilot study we decided to use a single search string. After several trials, we determined the following search line to be the most efficient: "Turkey OR Turkish OR Turk OR Istanbul OR Ankara OR İzmir."

Once the search line was determined, we chose Advanced Search and selected Agence France Presse as the news source. We did not determine a section search to ensure that every report that included the search terms would be returned. LexisNexis does not show full results for queries that bring more than 3,000 news reports. To restrict the results to under 3,000 for each query, we entered date specifications consisting of three- to six-month periods from January 1, 1990 to December 31, 2012. LexisNexis allows for 500 news reports at most in a single document for download. For each period, among the options available, we downloaded the news reports found through search terms in text format and full document view.

Because sports stories use words such as "attack, defensive, fight," etc., TABARI mistakes them for reports of conventional violence. The reformatting program, however, recognizes certain sports terms (e.g., "basketball" or "football") and automatically eliminates such stories. It also eliminates news summaries, which are repetitions of the previous week's news reports. 


\subsection{Reformatting news reports}

We saved all documents in a single folder. To reformat them, we also put the following three programs in that folder: NewNexisFormat.pl, nexisreverse.pl and LNAFP.seqsort. pl.24 In the Terminal (for Mac) or Command Prompt (for Windows), we located that folder. The Nexis downloads have a file name in the form "Agence_France_Presse_English2012-09-14_16-31.TXT," so we enter the command "ls Agence_Fr* > format. files" to generate a list of all documents beginning with "Agence_Fr." Then we enter the command "perl NewNexisFormat.pl TFP" to chop each downloaded document into separate paragraphs, excluding paragraphs that begin with quotation marks. The news story in the previous example is thus transformed into the format shown in Figure 2.

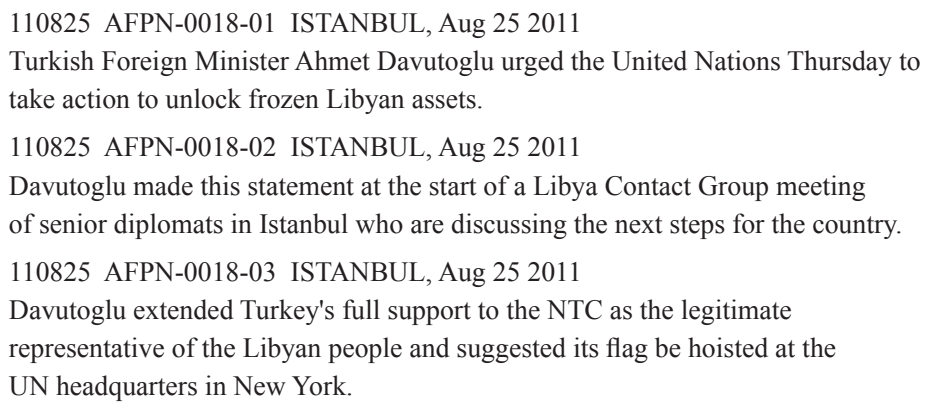

Figure 2: Formatted News Report

The program then gives each paragraph a tag line, as in Figure 3.

\section{(Date) (News Source)-(Number Of Report)-(Number Of Paragraph) (Place), (Month Day Year)}

Figure 3: Paragraph tag line

At this phase, the program runs with the dates and headlines of the various stories scrolling past as they are processed. If there is a format problem in the original downloaded document, the program stops working. For example, the program assumes that the story begins two lines after a line containing "DATELINE." This word is present in most but not all downloads. With an extensive search, we determined that various news stories in the late 1990s do not contain it, so we manually entered the dateline in the proper place. In another instance, although the stories included a dateline, several news reports about Turkey from July 1996 to January 1997 were not filtered by the reformatting program. We also found out that the program assumes that the first line in each news report is "Agence France Presse -English." In the aforementioned period, AFP decided to change this heading to "Agence France Presse" only. To thus ensure we were finding all applicable news stories, we opened the file in a word processor (easy to do because the downloaded reports are simple text documents), found all mentions of "Agence France Presse" and replaced them with "Agence France Presse -English" so that all reports would have the same first line. By doing this, we found 2,088 additional stories.

No AFP news articles about Turkey exist in LexisNexis before April 1991, and for reasons not known to us, there are no AFP news reports about any country for February 1992, March 1992, August 1992, or October 1995. Because these are missing in the original news source,

\footnotetext{
${ }^{24}$ All three reformatting programs can be found on the PSU Event Data Project website.
} 
they cannot be retrieved through AFP. In our full-scope project, we may be able to find news items for these dates through other sources.

After chopping with NewNexisFormat.pl, a filelist of the newly generated files is created with the "ls TFP* > filelist" command. The command "perl nexisreverse.pl" is entered so that only the first paragraph of a story is retrieved (i.e., with the "number of paragraph" in the story's tagline as “-01"). The resulting TABARI input sentences are then united in a single file called "reverse.output." At this point, the separate paragraphs (records) are usually not ordered chronologically so we enter the command "perl LNAFP.seqsort.pl reverse.output" to sort the records if they are out of order. The sorted output is placed in a file named "seqsort. reverse.output," however, this last program still puts records of stories from the 2000s at the beginning of the document, followed by stories from the 1990s.

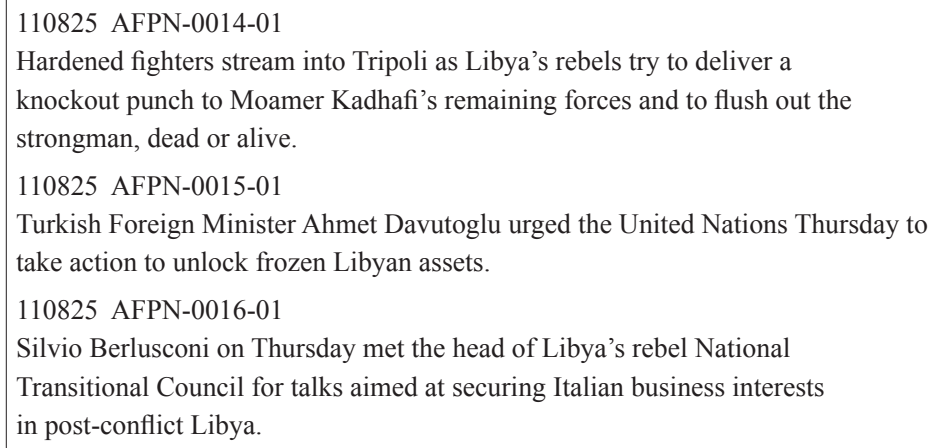

Figure 4: Formatted AFP News Leads

After the formatting, the news reports are reduced to the format shown in Figure 4.

In total, 91,542 news reports between April 27, 1991 and December 31, 2012 were reshaped into the above format. Almost half of these reshaped records do not contain actors from Turkey because the mentions of Turkey are in later paragraphs, which were cut out in the filtering process. To avoid reports of the same event, we chose to code only the first paragraph of each story instead of using full-text coding.

\subsection{Updating CAMEO project dictionaries}

TABARI recognizes sentence structures in the subject-verb-object form using dictionaries for those parts of speech, as well as for adjectives. It then determines whether each element of a sentence is an actor or event, and codes it accordingly.

Because CAMEO dictionaries were originally generated for scanning all global actors, its actor dictionary does contain terms for Turkey's actors, but they are limited in number and differentiation for the purposes of our study. The scope of a dictionary is determined by each researcher's focus, thus we are adding to CAMEO's actor dictionary to ensure TABARI will recognize all actors from Turkey. Table 1 compares previously generated datasets and TFAED. 
Table 1- Comparison of Dictionaries Used by Other Datasets

\begin{tabular}{l|l|l|l}
\hline & LEVANT DATASET & $\begin{array}{l}\text { OMUR YILMAZ'S TURKEY } \\
\text { DATASET }\end{array}$ & TFA DATASET \\
\hline TIME FRAME & Apr 1979-to Nov 2011 & Jan 1992 to Jul 2006 & Apr 1991 to Dec 2012 \\
\hline TOTAL ACTORS & 6099 lines & 3950 lines & 43125 lines \\
\hline TURKISH ACTORS & 59 Lines & 564 lines & 6012 lines \\
\hline TOTAL VERBS & 15787 & N/A & 17675 \\
\hline TOTAL NOUNS & 820 nouns & 280 nouns & 2254 nouns \\
\hline TOTAL ADJECTIVES & 114 adjectives & 50 adjectives & 324 adjectives, 328 agents \\
\hline TURKISH ACTOR CODES & 12 codes & 49 codes & 405 codes \\
\hline
\end{tabular}

For actor dictionaries, extensions are made by adding command lines for additional phrases to be coded as TUR***. We coded most phrases that begin with "Turkey's..." and "Turkish..." according to their roles, rather than simply as "TUR." This method allows us to differentiate between actors. For example, CAMEO originally coded the phrase "A boy of Turkish origin" as "TUR," a code which it also gives to "Turkey's artists" and "Turkish officials." In our expansion of the actor dictionary, "A boy of Turkish origin" is coded as "TRK" (ethnically Turkish); "Turkey's artists" are coded as "TURCUL" (cultural actors from Turkey); and "Turkish officials" as "TURGOV" (Government of Turkey). We also established different codes for government agencies, ministries, associations and foundations, armed rebel groups, opposition parties, civilians, ethnic and religious groups, Turkish cities, and different branches of the military.

Because this study focuses on actors from Turkey or people of Turkish origin in other countries (both as targets and sources), we used new specific codes for all actors from Turkey. For all other individuals, countries, and organizations, we retained the original CAMEO codes. For transnational actors affiliated with Turkey, however, we used a different scheme. Individuals, businesses, vessels with Turkish nationality, multinational corporations whose headquarters are in Turkey, non-governmental transnational movements or organizations that originated in Turkey, Turkish branches of non-governmental organizations, members of ethnic or religious groups who are Turkish nationals, and refugees from other countries who have settled in Turkey are all coded as actors from Turkey, hence their respective codes begin with "TUR". Their codes differentiate at the second tier; rather than assigning "NGO" to all non-governmental actors, these organizations are further differentiated by their type: "ASS" if an association, "FOU" if a foundation, "AID" if a relief agency, "RES" if a think tank or research group, "MED" if private media, "CVL" if a non-affiliated individual, etc. We also coded each Turkish city separately.

For governmental actors, we differentiated between president, prime minister, and individual ministries, as well as between state-owned enterprises and media. Political parties in office or that take part in the government are coded using their Turkish initials as the last three letters, for example, the Justice and Development Party is "TURGOVAKP" and the Democratic Left Party is "TURGOVDSP". Opposition parties are coded as "TUROPPMHP" (Nationalist Movement Party), "TUROPPDYP" (True Path Party), etc. In the actor dictionary, for phrases that denote political parties, separate codes are given for different time frames. For example, when "Democratic Left Party" appears in the record, TABARI looks at the date of the event to determine whether it should assign the event as "TURGOVDSP" or 
TUROPPDSP." "TURGOV" is only retained for general phrases, such as "Turkish officials" or "Turkish authorities," which are created automatically from our agent file (see next paragraph).

Table 2- Comparison of Codes

\begin{tabular}{c|c|c}
\hline PHRASE & TFAED CODE & CAMEO CODE \\
\hline TURKISH_RED_CRESCENT & {$[$ TURAID] } & [NGOTUR] \\
\hline TURKISH_GOVERNMENT & $\begin{array}{c}\text { TURURGOVDSP/TURGOVANP/ } \\
\text { TUROVMHP }<980529-021101]\end{array}$ & {$[$ TURGOV] } \\
\hline
\end{tabular}

We expanded CAMEO's verb dictionary to include over 2,000 new patterns and updated the verb codes to comply with the newest CAMEO Codebook standard. ${ }^{25}$ We also generated an agent's file, which is composed of generic nouns like "police," "student," "woman," etc., with each noun corresponding to a code. When TABARI finds an "agent" adjacent to an actor in a news report it combines both codes to specify it. For example, suppose there are codes for "Turkish" (TUR) and "Danish" (DNK) in the actor dictionary and for "police" (COP) in the agent dictionary. If the news report contains the phrase "Danish police and Turkish police will cooperate..." then TABARI codes the actors as DNKCOP and TURCOP respectively, even though the actor dictionary does not contain "Danish police" and "Turkish police." For this purpose, we scanned the noun codes from previous actor dictionaries and moved the relevant nouns into a separate document. We use our updated version of the CAMEO dictionary to look for nouns that may be useful for constructing an agent dictionary.

\subsection{Machine coding lead sentences}

After the necessary additions, thousands of reformatted news reports were ready for machine coding. For each input, TABARI generates corresponding event data. In some cases, the input does not contain all the items in the regular event-data format, that is, "who did what to whom and when." In such cases, no event data is generated from that record. In other cases, however, a single record such as a multilateral meeting contains more than one event datum because all actors are interacting with each other. The final formatting of AFP news before and after TABARI coding is shown in Figure 5.

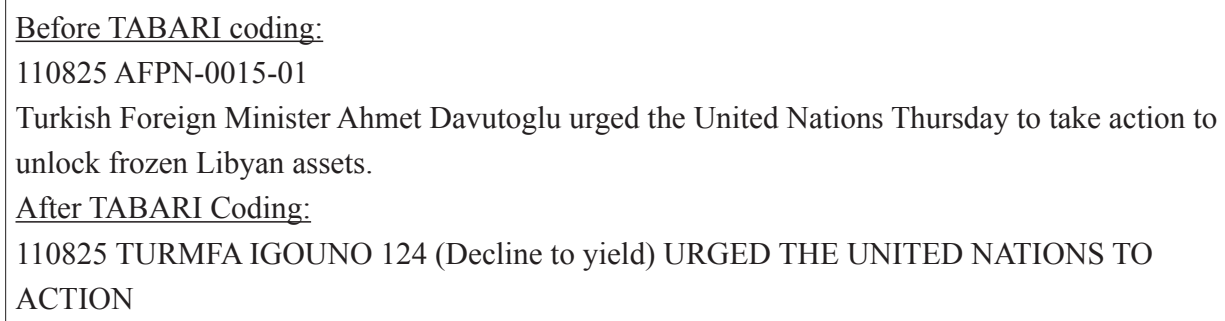

Figure 5. Coded AFP News Lead

${ }^{25}$ See Cameocodes Wiki Space, 2009: http://cameocodes.wikispaces.com. 
After machine coding, manual changes are done to the "raw reports," that is, those that TABARI failed to read. These errors usually occur either because there are too many verbs (TABARI distinguishes only a given number of verbs at most in a single sentence) or because dictionaries do not contain the relevant terms (for actors, verbs, etc.) With the manual additions, all reports have now been converted into event data.

\subsection{Processing event data}

To process the resulting event data, we used an open-access $\mathrm{R}$ program, specifically, the Events package created by Will Lowe in January 2012. ${ }^{26}$ This package allows the researcher to aggregate event data in terms of date, source or target type, and event type. It also enables the researcher to create scales by assigning numerical values to each event type or to use preestablished scales such as CAMEO's or WEIS's Goldstein scale. ${ }^{27}$

There are various options for aggregating event data in terms of actor type, and the selection depends on one's empirical object of study. For bilateral interstate relations, for example, aggregating data in terms of a country's relations with other countries in a particular region or continent is possible. For intrastate relations, aggregating data in terms of interactions among a country's domestic actors is possible. The data can also be aggregated in terms of the actor's initiative, that is, either who initiated the action (source) or who the action is directed at (target). Therefore, for any form of bilateral relationship, there are at least two groups of data: from Actor A to Actor B, and from Actor B to Actor A.

Data can also be aggregated in terms of time and event type. ${ }^{28}$ For the former, weekly, monthly, quarterly, and yearly aggregations can be made, and for the latter, there are basically two strategies. The first is to assign a number value to each event type, making a scale. The second is to differentiate between cooperative and conflictual events and between verbal and material actions. Then, for each dyad and time frame, the events that correspond to the resulting combinations (namely, "Verbal Conflict," "Material Conflict," "Verbal Cooperation," and "Material Cooperation") are counted. Other aggregation possibilities also exist, such as grouping event types in terms of content (namely, political, economic, or military).

After the data are aggregated, various visualization options can be considered to display it. Time-series graphs are the most common form of display. In a recent project, a dataset was created that also included actors' geographical locations, making it possible to display the data in map form. ${ }^{29}$

\section{Problems Encountered}

While conducting this pilot study, the research team encountered many challenges. One was institutional indifference, with lack of knowledge and interest great obstacles. Another was finding funding to support the project. Last, finding suitable research assistants that would work for the project's duration was one of the greatest challenges encountered.

\footnotetext{
26 "R: A language and environment for statistical computing," R Foundation for Statistical Computing, http://www.R-project. org/; "Events: Store and manipulate event data," R Project, http://CRAN.R-project.org/package=events.

27 Joshua S. Goldstein, "A Conflict-Cooperation Scale for WEIS Events Data," Journal of Conflict Resolution 36 (1992): 369385

28 James E. Yonamine, “Working with Event Data: A Guide to Aggregation Choices," (unpublished paper), accessed 25 April, 2013, http://jayyonamine.com/wp-content/uploads/2012/06/Working-with-Event-Data-A-Guide-to-Aggregation-Choices.pdf.

29 Leetaru and Schrodt, "GDELT."
} 


\subsection{Institutional indifference}

While developing the idea and project of quantifying Turkish foreign policy behavior, we observed that institutions have neither knowledge about nor interest in this subject. For example, we attempted to inform state institutions about the possible benefits of doing research in this area and explained that the analyses drawn from the dataset could contribute enormously to Turkey's policy making, but to no avail. Not only were they uninterested, they made substantial criticisms, arguing that because the dataset was created through news sources, it would include private information and hence be undesirable.

Indifference was not confined to state institutions; there was also a considerable lack of interest in academic circles. During our literature review, we observed that scholars working on Turkish foreign policy have not previously used this method and have generally preferred qualitative methods. Moreover, one academic who had used event data in her studies abroad and become quite knowledgeable about it, gave up using it after she came back to Turkey because her research interests changed.

We also encountered problems during our efforts to raise funds for the project through Scientific and Technological Research Council of Turkey (TUBITAK) grants. The main issue was in trying to shape our project to make it fit TUBITAK requirements. The bulk of the work for a project such as TFAED is in the coding process. Because the project is very comprehensive, it requires at least four "assistant researchers" and two "scholarship students" (TUBITAK terminology) to assist overall. Among the complications was TUBITAK's requirement that any scholarship students funded by the project should align their dissertation subject with the project. Including six people as "scholarship students" posed significant problems because it was impossible to find six who were interested in writing their dissertations on Turkish foreign policy and event data. The alternative was to hire a research firm and cover the costs under the expenditure item "service procurement." Unfortunately, this was not possible either because there is no firm in Turkey with the relevant expertise.

Finally, after discussions with TUBITAK, we reached a solution: the project coordinators would recruit and train research assistants who would then be hired under "service procurement." If the project is ultimately accepted by TUBITAK, then at least this personnel problem will have been solved.

\subsection{Financial problems}

We have also expended considerable effort to procure government support for events and gatherings such as the December 2011 Event Data Workshop, which indirectly benefited the TFAED project. The Turkish government did support this event and granted the necessary permissions and approvals, but the funds were delayed because of bureaucratic obstacles, which in turn delayed organizing the workshop.

\subsection{Fleeing assistant}

Those who work on our project must be trained in event data methodology. They must also be able to use certain software programs and be skilled in machine coding. Moreover, the project requires long-term commitment (three to four years) and endurance. If there are conflicting interests in the assistant's life, the former may be an issue. The latter is also important; the assistant may find the routine tedious, but he or she should be committed to continue with the project. 
In Turkey, social science graduate students are not usually oriented toward quantitative methodology and statistical methods (exceptions are in economics, psychology, and, to a much lesser extent, sociology), nor are they experienced in long-term projects that demand commitment. During the interviews we conducted with potential assistants, some of them flinched and fled after being told about the nature of this project. Moreover, some assistants who had already begun work on the project showed signs of reluctance after they realized that the work would take a long time to complete. Such experiences, however, have helped us develop new ways to explain the project and to train assistants to reduce potential intimidation and flight.

\section{Preliminary Findings}

In the last decade, Turkey's foreign policy actors, the foreign actors they engage with, and the relations they have established have not only numerically increased but grown ever more complicated. The primary impetus for this project emerges out of curiosity and a substantial disagreement among Turkish foreign affairs scholars about fundamental questions regarding Turkey's activism, ${ }^{30}$ such as the geographical focus of Turkey's foreign affairs, the role of non-state actors in Turkish foreign affairs, Turkey's behaviors toward Israel, and Turkey's zero-problems-with-neighbours policy. We present data relevant to these questions, which could subsequently be explored through rigorous statistical methods to analyze patterns in time, actors, and event types. The purpose of this paper is to demonstrate the potential uses of an event dataset specifically designed to portray Turkey's foreign affairs, rather than to make more elaborate inferences.

\subsection{Axis shift}

Over the last ten years, one of the questions that scholars studying Turkey's foreign affairs have asked is whether the ruling AKP's foreign policy reflects a definite change from the past in terms of its geographical focus. The "new" focus of Turkey's international relations has been variously defined as "the Muslim World," "the neighbourhood," or "the whole world." ${ }^{31}$ It has been argued that the bilateral dynamics between Turkey and the EU/US have changed, ${ }^{32}$ and that Turkey has been seeking ways to strengthen its relations with nonWestern societies. ${ }^{33}$

Figure 6 shows Turkish government and non-state actors' actions toward any foreign actor, including actors in Turkey who are not Turkish, for example, Chechens, Kurds, or Syrian refugees. The graph shows that while the Turkish government was particularly active in early 2003, late 2004, and late 2009, its overall activity level has not significantly changed since the second half of the 1990s.

\footnotetext{
30 Ersel Aydınl, Gonca Biltekin, and Musa Tuzuner, “Time to Quantify Turkey’s Foreign Affairs: Setting Standards for a Maturing International Relations Discipline" (forthcoming); Ersel Aydınlı, Gonca Biltekin, and Musa Tuzuner, "Quantification of Turkey's Foreign Affairs via Event Data" (paper presented at the Workshop on Quantifying Security Studies and Foreign Policy Analysis in Turkey and the Greater Middle East, December 2-4, 2011, Istanbul).

31 Mesut Özcan and Ali Resul Usul, "Understanding the "New" Turkish Foreign Policy: Changes within Continuity, Is Turkey Departing From The West?" Uluslararası Hukuk ve Dış Politika 6, no. 21 (2010): 101-123; Bülent Aras and Hakan Fidan, "Turkey and Eurasia: Frontiers of a New Geographic Imagination," New Perspectives on Turkey 40 (2009): 195-217.

32 Tarık Oğuzlu and Mustafa Kibaroğlu, "Is the Westernization Process Losing Pace in Turkey: Who's to Blame?" Turkish Studies 10, no. 4 (2009): 577-593; Tarık Oğuzlu, "Middle Easternization of Turkey's Foreign Policy: Does Turkey Dissociate from the West?" Turkish Studies 9, no. 1 (2008): 3-20; Fiona Hill and Omer Taspinar, "Turkey and Russia: Axis of the Excluded?" Survival 48, no. 1 (2006): 81-92; Ziya Meral and Jonathan Paris, "Decoding Turkish Foreign Policy Hyperactivity," The Washington Quarterly 33, no. 4 (October 2010): 75-86.

${ }^{33}$ İbrahim Kalın, “Turkey and the Middle East: Ideology or Geo-politics?” Private View (2008): 29.
} 


\section{| Non-State | Turkish Government}

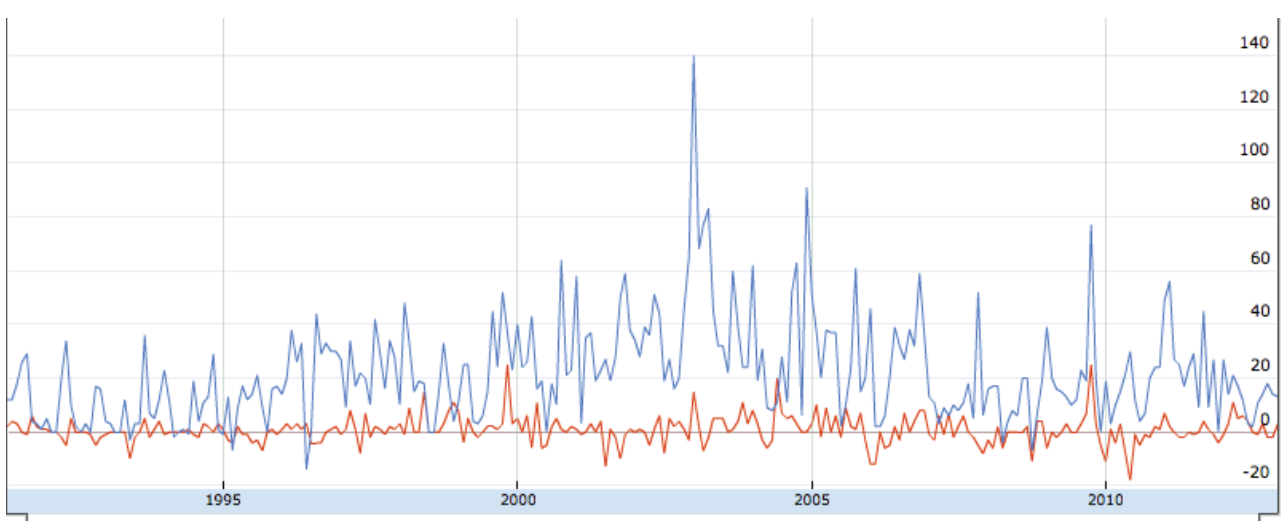

Figure 6: Turkish Government and Non-State Actors to World Regions (Cooperation-Conflict), 1991-2012

To more closely examine Turkey's geographical focus over the last 22 years, we aggregated the world's countries into seven geographical regions. If an intergovernmental or transnational organization's membership is region-specific (as is the EU's), we included the organization in the corresponding region. We did not include ethnic or religious groups whose nationalities were not identified in news reports, nor did we include transnational organizations/movements. We also eliminated the behaviors of non-state actors from Turkey toward non-Turkish actors so as to capture only the Turkish government's behavior. We aggregated the types of actions along two categories (cooperation vs. conflict) and counted them on a monthly basis. Then, we subtracted total conflictual event counts from total cooperative event counts for each month. Finally, we separated the data into two periods (1991-2002 and 2003-2012) for more detailed visualization. As evident from Figures 7 and 8, European countries have long been an important cooperation partner for Turkish governments. Consistent with Turkey's attempts to attain EU membership, most peaks in Turkish governments' bilateral interactions are with Europe. That trend continues well into 2007, after which relations with other regions become more prominent.

One such region is the Middle East. While there were considerable cooperative actions with the Middle East in the pre-AKP period, since 2003 relations have seen a remarkable boost. On the other hand, conflict with the Middle East has also increased compared to earlier periods. 


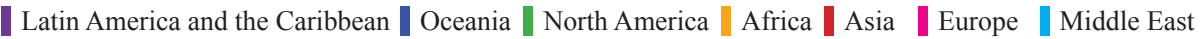

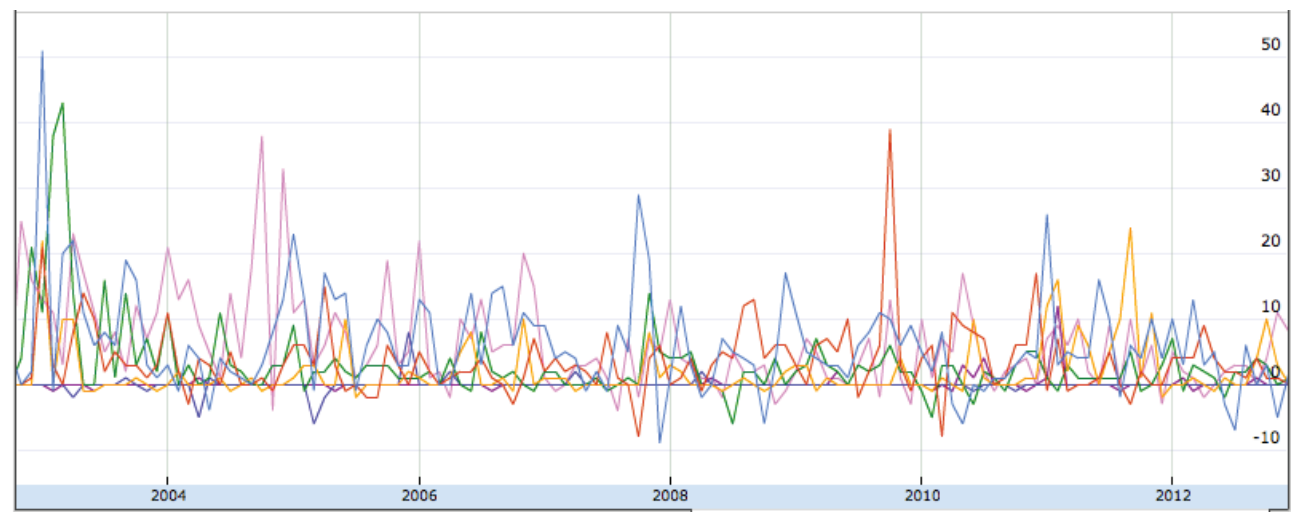

Figure 7: Turkish Government to World Regions, 2003-2012

A closer look at the two periods reveals that the AKP period (2003-2012) has also been different in terms of relations with Africa. While there were occasional conflicts with African countries in late 1990s and early 2000s, relations rarely took a negative turn between 2003 and 2012, and peaked positively in mid-2011. With North American countries, however, it has been the reverse. While the figure shows almost no downturns before 2003, it seems there have been occasional conflicts with that region since 2008 .

Oceania and Latin America are the least-reported regions with respect to their relations with the Turkish government in both periods, but there has been more interaction with Latin America and less interaction with Oceania in the latter period compared to the pre-AKP period.

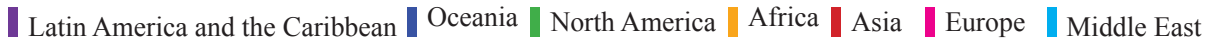

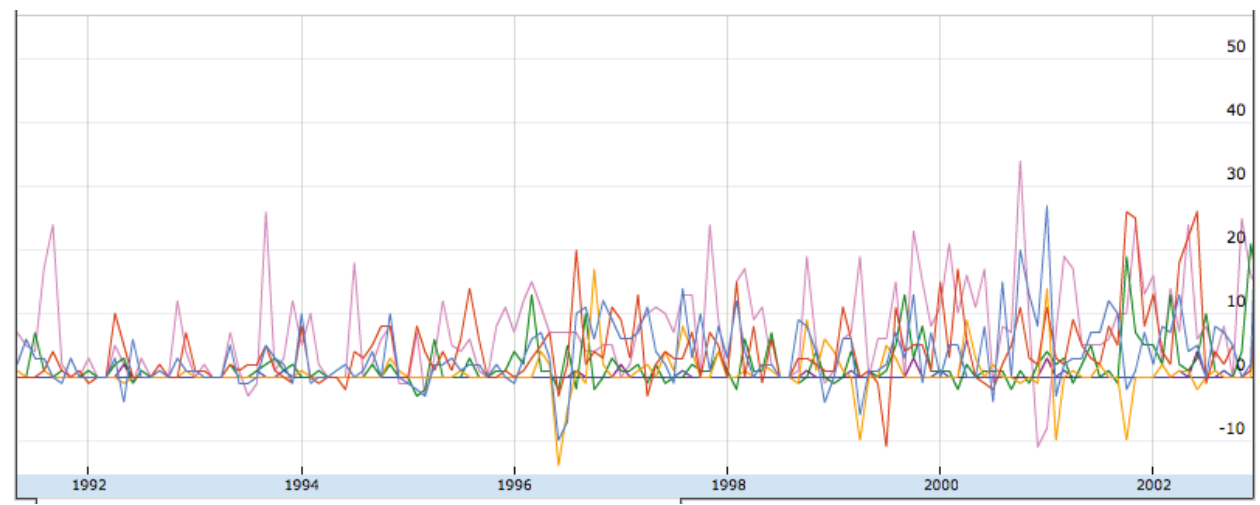

Figure 8: Turkish Government to World Regions, 1991-2003 
I Turkish Government to Europe I Turkish Government to the Middle East

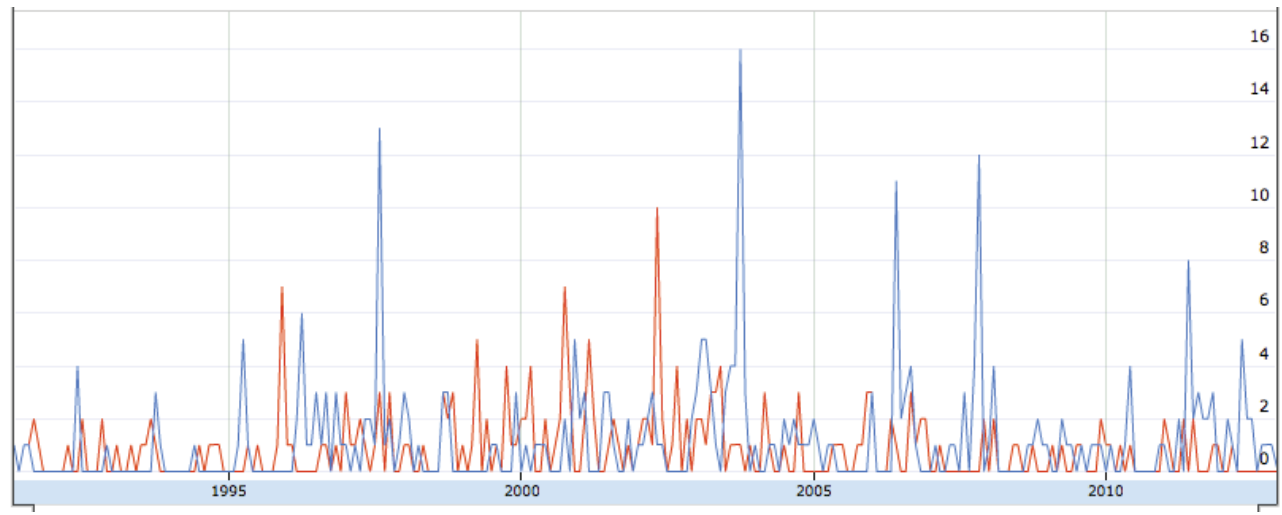

Figure 9: Turkish Government to Europe vs. Turkish Government to the Middle East, 1991-2012

Considering the debates about Turkey's diminishing relations with Europe and its improving relations with the Middle East, a comparative look at the Turkish government's material cooperation with the two regions may provide some insight. Figure 9 shows materially cooperative actions from the Turkish government to both regions in monthly counts.

The increasing prominence of the Middle East in Turkish foreign policy is more apparent after 2004. It is interesting to see that even at the height of Turkey's relations with the EU (in 2005, when accession talks began) material cooperation was apparently relatively low with Europe. On the other hand, as the event data is only gathered from news reports, they might inadequately represent ongoing lesser-level bureaucratic interactions because these have less journalistic value.

\subsection{Non-state actors in Turkish foreign affairs}

With the democratization and Europeanization processes, it has been argued that non-state actors, such as business and research organizations and others, have become increasingly active in foreign matters. ${ }^{34}$ To explore this claim, we aggregated our data into three actor groups: Turkish government, Turkish non-state actors, and non-Turkish actors. Figure 10 shows Turkish non-state actors' actions toward the world (including all religious and ethnic groups not identified with any single country). Events are not aggregated in terms of type, but counted on a monthly basis to determine the overall initiative.

${ }^{34}$ Sedat Laçiner, "Yeni Dönemde Türk Dış Politikasının Felsefesi, Fikri Altyapısı ve Hedefleri," in Yeni Dönemde Türk Dlş Politikası: Uluslararası IV. Türk Dış Politikası Sempozyumu Tebliğleri, eds. Osman Bahadir Dincer, Habibe Özdal, and Hacali Necefoğlu (Ankara: USAK, 2010); Altay Atl1, "Businessmen as Diplomats: The Role of Business Associations in Turkey's Foreign Economic Policy," Insight Turkey 13, no.1 (2011): 109-128; Ziya Öniş, "Multiple Faces of the "New" Turkish Foreign Policy: Underlying Dynamics and a Critique," Insight Turkey 13, no. 1 (2011): 47-65; Kemal Kirişçi, "The Transformation of Turkish Foreign Policy: The Rise of the Trading State," New Perspectives on Turkey 40 (2009): 29-57; İbrahim Kalın, "Turkey and the Middle East," 29; Mustafa Kutlay, "Economy as the 'Practical Hand' of 'New Turkish Foreign Policy': A Political Economy Explanation," Insight Turkey 13, no. 1 (2011): 67-88. 


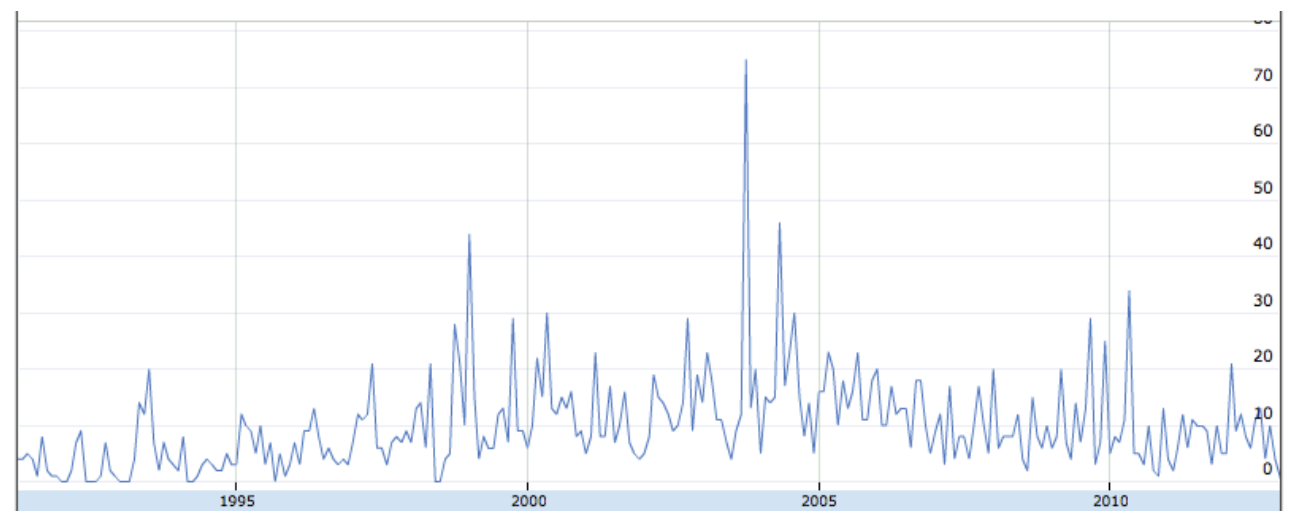

Figure 10: Turkish Non-State Actors to World, 1991-2012

According to our data, despite occasional peaks in late 2003 and 2004 (which account for more than $40 \%$ of all actions in those months), Turkish non-state actors have not been particularly active in foreign affairs. While their impact on government policy formulation might have increased, their foreign behavior has not significantly increased. To track nonstate actors' overall weight (i.e., how much foreign affairs action in Turkey is conducted by non-state actors), we counted all their actions toward the world and divided them by all event counts from all Turkey's actors to the world. (see figure 11) (Non-state actors' overall effect on Turkish foreign affairs can only be portrayed by also considering some other factors (such as their impact on policy formulation), which is beyond the scope of this study.)

I Non-state | Government

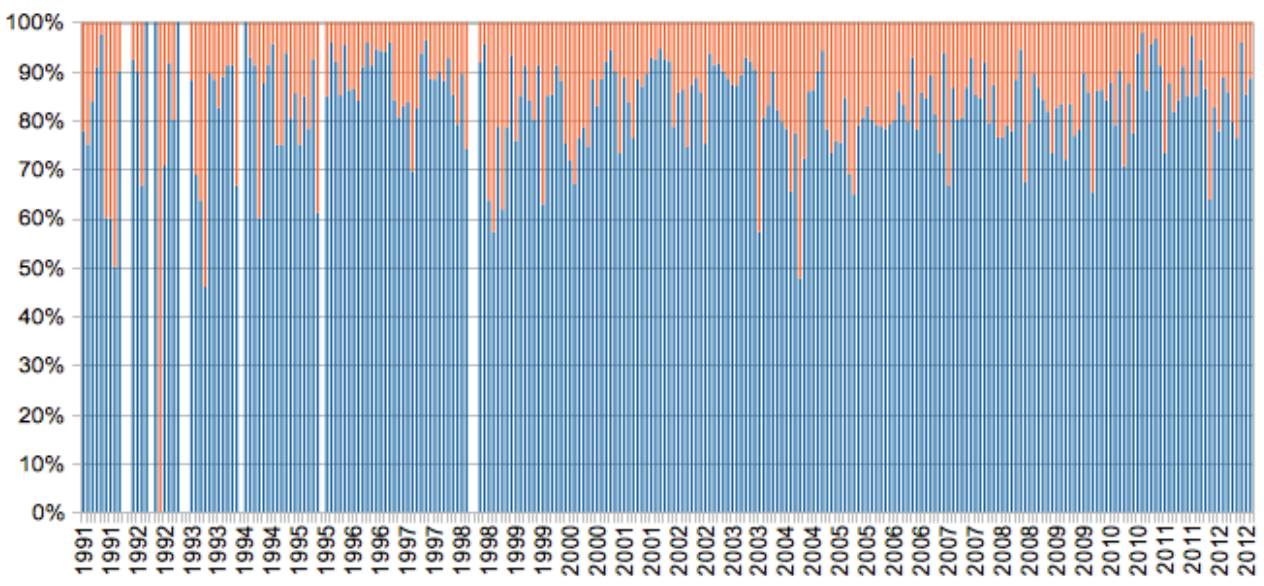

Figure 11: Non-State Actors' Overall Weight in Turkish Foreign Affairs

\subsection{Turkey-Israel relations}

Recently, Turkey's relations with Israel have taken a significant downturn compared to the late 1990s. Observers have argued that Turkish-Israeli relations have deteriorated especially since the AKP has come to power. ${ }^{35}$ Prime Minister Erdoğan's criticisms concerning Israel's

\footnotetext{
35 Tarkk Oğuzlu, "The Changing Dynamics of Turkey-Israel Relations: A Structural Realist Account," Mediterranean Politics
} 15 , no. 2 (2010): 273-288. 
policy in the West Bank and Gaza as well as about the 2010 Israeli attack on Turkey's Gaza aid flotilla have caused setbacks between the countries. ${ }^{36}$ Consequently, the most dramatic shifts in Turkish foreign policy can be witnessed in Turkey-Israeli relations. ${ }^{37}$

Some scholars have pointed out that positive public opinion in Turkey toward Palestinians makes Turkish decision makers especially sensitive to the level of conflict between Israel and Palestine, which in turn affects relations between Turkey and Israel. ${ }^{38}$ Another scholar explains the volatility in relations as emanating from a lack of "material infrastructure" as well as having a "social basis." ${ }^{39}$ Therefore, Turkey-Israeli relations take place in a mostly discursive sphere.

Figure 12 shows the actions of all Turkish actors toward Israel. Event types are aggregated in four categories on a monthly basis. We labeled some peaks to highlight important turning points in the countries' relations. It seems that an increasing level of conflict between Israel and Palestine has affected Turkey's relations with Israel in the pre-AKP and AKP periods, with Turkey responding vociferously to Israeli actions. Turkey's mediation efforts from 2003 to 2005 and in early 2010 concerning the Middle Eastern conflict are also apparent in the figure.

| Material Cooperation || Verbal Conflict || Material Conflict || Verbal Cooperation

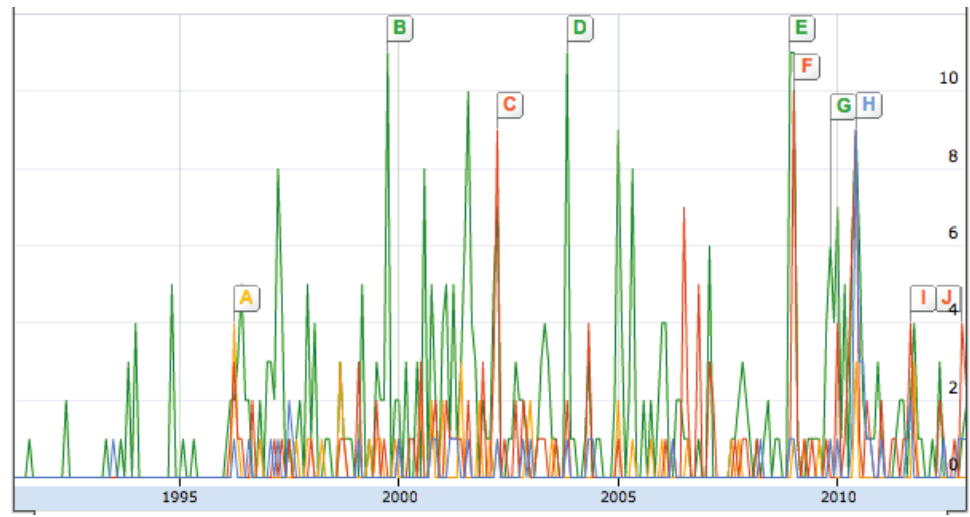
J. Operation Pillar of Defense
I. Suspension of military agreements
H. Gaza flotilla raid
2010-6-1
G. Turkish ambassador crisis
F. One minute
F. One minute
E. Gaza war
2008-12-
D. 2003 Istanbul synagogue bombings
c. Operation Defensive Shield in the West Bank 2002-4-1
B. Ehud Barak visits TR 1999-10-1
A. Military agreement

Figure 12: Turkey to Israel, 1991-2012

Figure 13 provides a closer look at the material and verbal actions from Turkey toward Israel. The material conflict monthly event counts and verbal conflict monthly event counts are inverted. The data shows that in the pre-2003 period, Turkey's relations with Israel were denser both verbally and materially (rarely a month passed with no actions from Turkey toward Israel) than they were in the post-2003 period. While material relations were mostly cooperative, there were some verbal confrontations. In the post-2003 period, the overall number of material interactions has declined and there have been more verbal and material conflicts between Turkey and Israel.

${ }^{36}$ Stephen F. Larrabee, “Turkey Rediscovers Middle East,” Foreign Affairs 86, no. 4 (2007): 110

${ }_{37}$ Joshua Walker, "Learning Strategic Depth: Implications of Turkey’s New Foreign Policy Doctrine," Insight Turkey 9, no.3 (2007): 32-47.

${ }^{38}$ Saziya Burcu Giray, "Turkish Policy towards the Israeli-Palestinian Conflict," in Muslim Attitudes to Jews and Israel:The Ambivalences of Rejection, Antagonism, Tolerance and Cooperation, ed. Moshe Maoz (Eastbourne: Sussex Academic Press, 2012): 174.

39 Gökhan Bacık, “Turkish-Israeli Relations after Davos: A View from Turkey,” Insight Turkey 11, no. 2 (2009): 31-41. 
| Material Cooperation | Verbal Cooperation | Verbal Conflict | Material Conflict

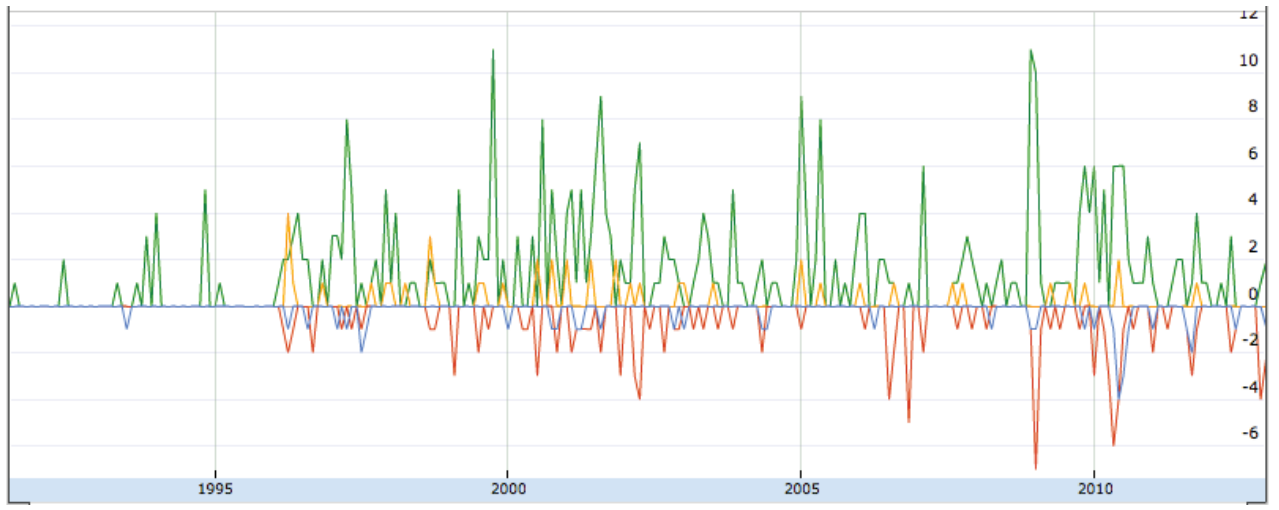

Figure 13: Turkey to Israel, 1991-2012

\subsection{Zero-problem neighbourhood}

One of the major novelties in recent Turkish foreign policy discourse has been Davutoğlu's principle of "zero problems with neighbours." It is argued that Turkey's relations with its neighbours have been on a more cooperative track than in the past, and include bilateral political, economic, and military relations. ${ }^{40}$ With a liberal outlook, Turkish policymakers have sought to increase Turkey's ties with neighbouring countries, which, in at least one scholar's view, has turned into a complex interdependence ${ }^{41}$ Accordingly, bilateral dialogue rather than more coercive options has been the primary instrument of interaction. ${ }^{42}$

Figures 14 and 15 show various dimensions of Turkey's relations with its neighbours, who consist of individuals, groups, and organizations from every country with which Turkey shares a territorial border. Event types are aggregated into twelve categories on a monthly basis: first as conflict-cooperation, then as verbal and material, and last as military, economic, and political. Military actions are defined as all appeals, expression of intents, demands, threats, rejections, agreements of a military or intelligence nature, provision of military aid or refusal of such, as well as direct and non-direct violent actions or their de-escalations. Economic events are all appeals, expression of intents, demands, threats, rejections, agreements of an economic nature, provision of economic or humanitarian aid or refusal of such, as well as boycotts, strikes, blockades, embargoes, and damages to property, or their de-escalations. Political events are all other events, including all actions of a judicial and legal nature. All conflict events are inverted. Figure 14 shows the material actions and Figure 15 shows verbal actions.

${ }^{40}$ Ahmet Davutoğlu, “Turkey's Zero-Problems Foreign Policy," Foreign Policy, May 10, 2010, accessed May 9, 2013, http:// jft-newspaper.aub.edu.lb/reserve/data/s11244/s11244.pdf.

${ }^{41}$ Kadri Kaan Renda, “Turkey's Neighbourhood Policy: An Emerging Complex Interdepence," Insight Turkey 3, no. 1 (2011): 90 .

${ }^{42}$ Renda, "Turkey's Neighbourhood," 105. 
【Coop.Mat.Pol | Coop.Mat.Mil | Coop.Mat.Eco \Conf.Mat.Pol |Conf.Mat.Mil |Conf.Mat.Eco

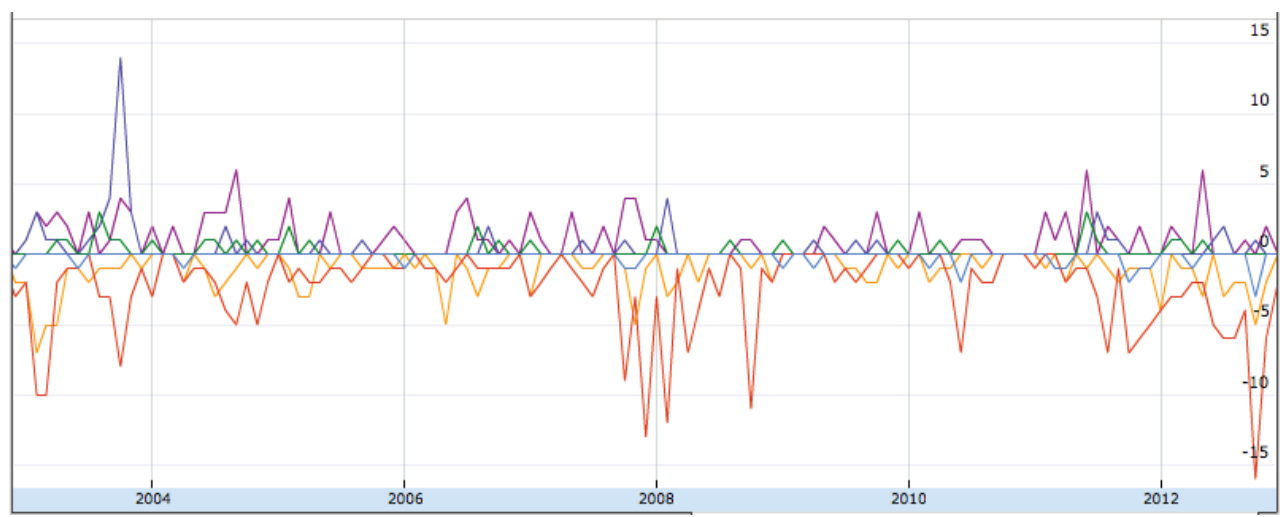

Figure 14: Turkey to Neighbours (Material Conflict vs. Material Cooperation), 2003-2012

When we look at the material event counts, military conflicts with neighbours have been most visible in late 2007 and early 2008, when the Turkish military conducted military operations against the Kurdistan Workers' Party (PKK) in northern Iraq, and in October 2012, when Turkey responded to Syrian attacks on its border. Turkey's material cooperation with its neighbours has had more of a political character than a military or economic one. With respect to verbal actions, from 2011 onwards, Turkey has been more likely to verbally confront its neighbours.

I Coop.Verb.Pol |Coop.Verb.Mil | Coop.Verb.Eco |Conf.Verb.Pol | Conf.Verb.Mil | Conf.Verb.Eco

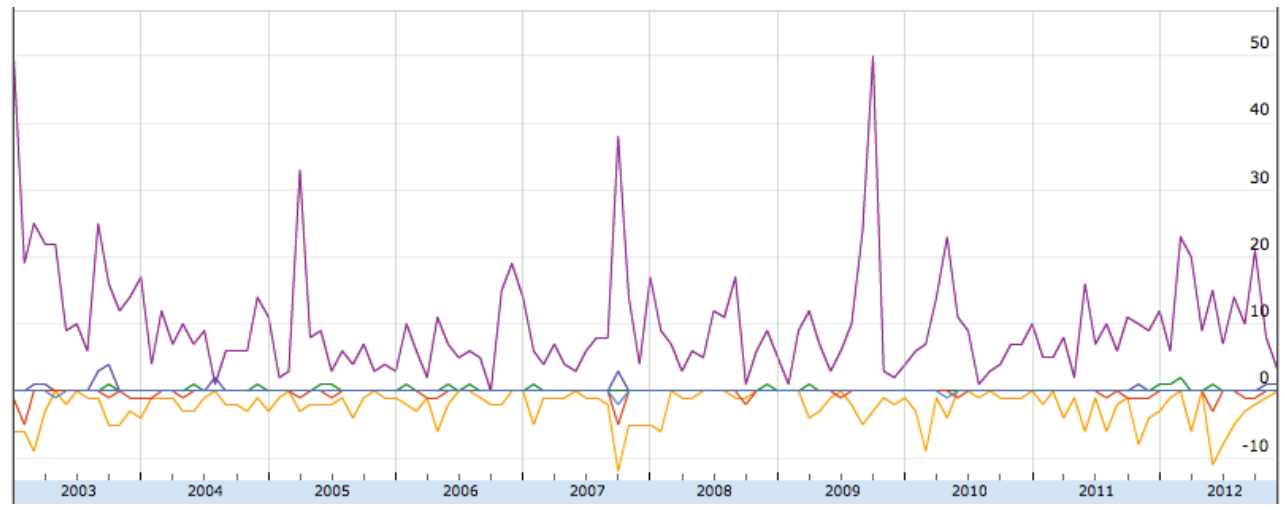

Figure 15: Turkey to Neighbours (Verbal Conflict vs. Verbal Cooperation), 2003-2012

Whether or not Turkey has managed to turn its activism into economic, diplomatic, and political capital is also an interesting question. ${ }^{43}$ To gain a sense of how Turkey's neighbours have responded to its new activism, see Figures 16 and 17. 
| Coop.Mat.Pol | Coop.Mat.Mil | Coop.Mat.Eco | Conf.Mat.Pol | Conf.Mat.Mil| Conf.Mat.Eco

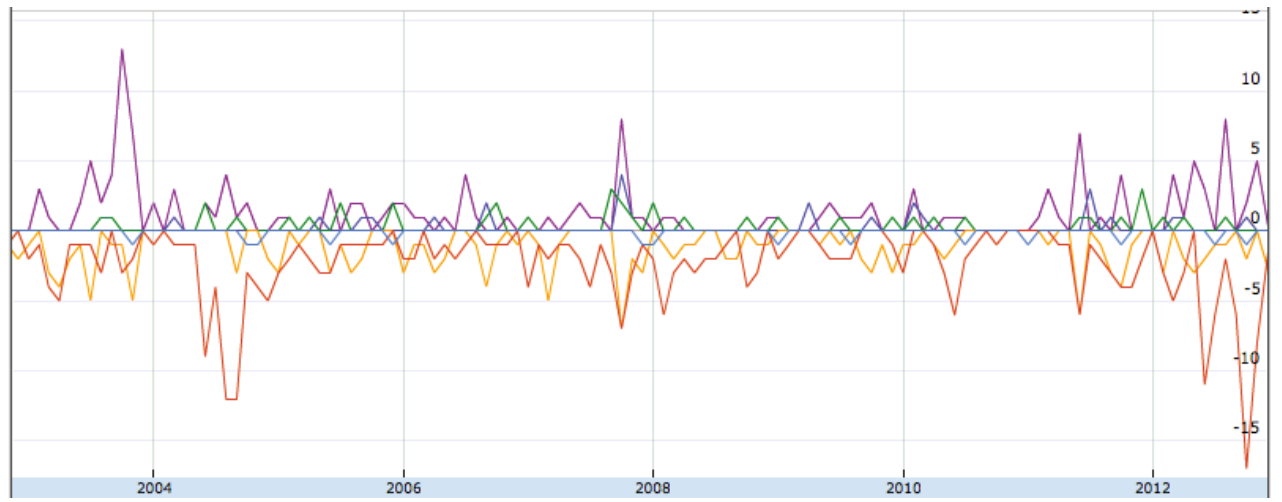

Figure 16: Neighbours to Turkey (Material Conflict vs. Material Cooperation), 2003-2012

I Coop.Verb.Pol | Coop.Verb.Mil | Coop.Verb.Eco |Conf.Verb.Pol |Conf.Verb.Mil | Conf.Verb.Eco

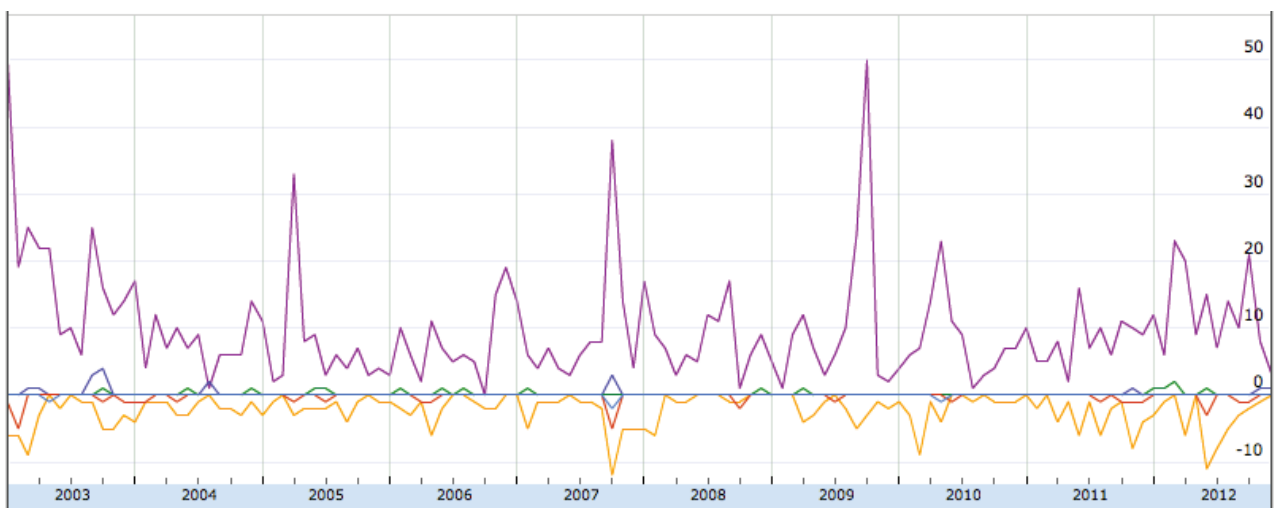

Figure 17: Neighbours to Turkey (Verbal Conflict vs. Verbal Cooperation), 2003-2012

When we compare Turkey's actions toward its neighbours, and its neighbours' actions toward Turkey, it seems that bilateral relations have been more or less reciprocal. Since 2011, neighbours' material military confrontations with Turkey have gradually increased, peaking in late 2012. Usually, politically cooperative gestures from neighbours accompany these confrontations.

\section{Conclusion}

As this pilot study of the TFAED project shows, this dataset has the potential to answer, in a quantitative manner, various fundamental questions about Turkey's foreign affairs. Because detailed generic codes are produced with respect to actors, and coding categories are extensive, researchers are able to regroup data in diverse ways, for example, according to actor type, event type, and timespan. These groupings make it possible to test various hypotheses and compare them with each other.

The dataset enables researchers to answer general questions regarding Turkey's foreign 
policy behavior in a more reliable manner. Is the nature of Turkey's relations with Country X/ Region Y cooperative or conflictual? Has such cooperation/conflict been military, economic, or cultural? Is cooperation with Country $\mathrm{X}$ greater than cooperation with Country Y? Is conflict with Country X physical or verbal?

Grouping the data according to timespan will help researchers make historical comparisons with respect to the behaviors of the same actor. It will also be possible to identify patterns in Turkish foreign policy before and after important events, such as the Mavi Marmara incident, the war in Iraq, the 2003 and 2007 general elections, the beginning of EU membership accession talks in 2005, etc. Moreover, some less dramatic yet equally important time periods might be identified.

Via this dataset, research questions about Turkey's domestic inter-actor cooperation and conflict can be analyzed over time and across various domestic groups, as well as their relations with foreign actors. Tests for dependence between domestic and foreign relations can be conducted to see if any domestic relations affect or are affected by foreign relations.

Some statistical models can be applied to the data to predict the future course of events between two actors. Such predictive capability may prove beneficial to policymakers to devise strategies for coping with potential crises and problems.

Finally, the dataset may prove beneficial for conceptualization through inductive reasoning. Once the patterns, trends, and orientations are identified with respect to the above questions, any shift with respect to them will generate causal questions, which in turn will instigate the formation of new conceptual tools. Therefore, TFAED can also be used for exploring new venues for generating theoretical frameworks in addition to testing the hypotheses generated from existing ones.

\section{Bibliography}

Aras, Bülent, and Hakan Fidan. “Turkey and Eurasia: Frontiers of a New Geographic Imagination.” New Perspectives on Turkey 40 (2009): 195-217.

Atlı, Altay. "Businessmen as Diplomats: The Role of Business Associations in Turkey's Foreign Economic Policy." Insight Turkey 13, no.1 (2011): 109-128.

Aydınl, Ersel and Musa Tuzuner, "Quantifying intelligence cooperation: The United States International Intelligence Behavior (USIIB) dataset.” Journal of Peace Research 48, no. 5 (2011): 673-682.

Aydınl, Ersel, Gonca Biltekin, and Musa Tuzuner. "Quantification of Turkey’s Foreign Affairs via Event Data." Paper presented at the Workshop on Quantifying Security Studies and Foreign Policy Analysis in Turkey and the Greater Middle East, İstanbul, December 2-4, 2011.

Aydınl, Ersel, Gonca Biltekin, and Musa Tuzuner. “Time to Quantify Turkey’s Foreign Affairs: Setting Standards for a Maturing International Relations Discipline" (forthcoming).

Azar, Edward E. "The Conflict and Peace Data Bank (COPDAB) Project." The Journal of Conflict Resolution 24, no. 1 (1980): 143-152.

Bacık, Gökhan. “Turkish-Israeli Relations after Davos: A View from Turkey.” Insight Turkey 11, no. 2 (2009): 31 41.

Bond, D., and W. B. Vogele. "Profiles of International Hotspots." Unpublished manuscript, 1995. Center for International Affairs, Harvard University. Accessed August 19, 2011. http://vranet.com/papers.html.

Bond, Doug, Joe Bond, Churl Oh, J. Craig Jenkins, and Charles Lewis Taylor. "Integrated Data for Events Analysis (IDEA): An Event Typology for Automated Events Data Development.” Journal of Peace Research 40, no. 6 (2003): 733-745.

Bond, Doug, and Joe Bond, 1995. Panda Codebook. Cambridge, MA: The Program on Nonviolent Sanctions and 
Cultural Survival, Weatherhead Center for International Affairs, Harvard University.

Cameocodes. “Cameocodes Wiki Space.”Accessed August 19, 2011. http://cameocodes.wikispaces.com.

Davis, David R., Brett Ashley Leeds, and Will H. Moore "Measuring Dissident and State Behaviour: The Intranational

Political Interactions (IPI) Project." Paper presented at the Workshop on Cross-National Data Collection, Texas A\&M University, November 21, 1998.

Davutoğlu, Ahmet. "Turkey’s Zero-Problems Foreign Policy.” Foreign Policy, May 10, 2010. Accessed May 9, 2013. http://jft-newspaper.aub.edu.lb/reserve/data/s11244/s11244.pdf.

Engene, Jan Oskar. "Five Decades of Terrorism in Europe: The TWEED Dataset." Journal of Peace Research 44, no. 1 (2007): 109-112.

Francisco, Ronald A. "The Relationship between Coercion and Protest: An Empirical Evaluation in Three Coercive States." The Journal of Conflict Resolution, Vol. 39, No. 2 (1995):263-282.

Franzosi, R. "The Press as a Source of Sociohistorical Data." Historical Methods 20, no. 1 (1987): 5-16.

Giray, Saziya Burcu. "Turkish Policy towards the Israeli-Palestinian Conflict." In Muslim Attitudes to Jews and Israel:The Ambivalences of Rejection, Antagonism, Tolerance and Cooperation, edited by Moshe Maoz, 169185. Eastbourne: Sussex Academic Press, 2012.

Goldstein, Joshua S. “A Conflict-Cooperation Scale for WEIS Events Data." Journal of Conflict Resolution 36 (1992): 369-385.

Hill, Fiona, and Omer Taspinar. “Turkey and Russia: Axis of the Excluded?” Survival 48, no. 1 (2006): 81-92.

Houghton, Brian K. "Terrorism Knowledge Base: A Eulogy (2004-2008).” Perspectives on Terrorism 2, no. 7 (2008): 18-19.

Howell, Llewellyn D., and Gillian Barnes. "Event Data for Region-Specific Interactions: A Research Note on Source Coverage.” In International Event-Data Developments: DDIR Phase II, edited by Richard L. Merritt, Robert G. Muncaster, and Dina A. Zinnes, 45-54. Ann Arbor: University of Michigan Press, 1993.

Kalın, İbrahim. "Turkey and the Middle East: Ideology or Geo-politics?” Private View (2008): 26-35.

Kirişçi, Kemal. "The Transformation of Turkish Foreign Policy: The Rise of the Trading State." New Perspectives on Turkey 40 (2009): 29-57.

Kutlay, Mustafa. "Economy as the 'Practical Hand' of 'New Turkish Foreign Policy': A Political Economy Explanation.” Insight Turkey 13, no. 1 (2011): 67-88.

Laçiner, Sedat. "Yeni Dönemde Türk Dış Politikasının Felsefesi, Fikri Altyapısı ve Hedefleri." In Yeni Dönemde Türk Dış Politikası: Uluslararası IV. Türk Dış Politikası Sempozyumu Tebliğleri, edited by Osman Bahadir Dincer, Habibe Özdal, and Hacali Necefoğlu. Ankara: USAK, 2010.

Larrabee, Stephen F. “Turkey Rediscovers Middle East.” Foreign Affairs 86, no. 4 (2007): 103-114.

Leetaru, Kalev, and Philip A. Schrodt. “GDELT: Global Data on Events, Location and Tone 1979-2012.” Paper presented at the International Studies Association meetings, San Francisco, April 2013.

McClelland, Charles A. World Event/Interaction Survey (WEIS) 1966-1978 (ICPSR5211). Ann Arbor, Michigan: Inter-University Consortium for Political and Social Research, 1978.

Meral, Ziya, and Jonathan Paris. "Decoding Turkish Foreign Policy Hyperactivity.” The Washington Quarterly 33, no. 4 (October 2010): 75-86.

Oğuzlu, Tarık, and Mustafa Kibaroğlu. "Is the Westernization Process Losing Pace in Turkey: Who's to Blame?" Turkish Studies 10, no. 4 (2009): 577-593.

Oğuzlu, Tarık. “Middle Easternization of Turkey’s Foreign Policy: Does Turkey Dissociate from the West?” Turkish Studies 9, no. 1 (2008): 3-20.

Oğuzlu, Tarık. "The Changing Dynamics of Turkey-Israel Relations: A Structural Realist Account." Mediterranean Politics 15, no. 2 (2010): 273-288.

Olzak, S. "Analysis of Events in Studies of Collective Actions." Annual Review of Sociology 15 (1989): 119-141.

Öniş, Ziya. "Multiple Faces of the "New" Turkish Foreign Policy: Underlying Dynamics and a Critique." Insight Turkey 13, no. 1 (2011): 47-65. 
Özcan, Mesut, and Ali Resul Usul. "Understanding the "New" Turkish Foreign Policy: Changes within Continuity, Is Turkey Departing From The West?” Uluslararası Hukuk ve Dış Politika 6, no. 21 (2010): 101-123.

R Foundation for Statistical Computing . "R: A Language and Environment for Statistical Computing." http:// www.R-project.org/.

R Project. "Events: Store and Manipulate Event Data," http://CRAN.R- project.org/package=events.HYPERLINK.

Renda, Kadri Kaan. “Turkey’s Neighbourhood Policy: An Emerging Complex Interdepence.” Insight Turkey 13, no. 1 (2011): 89-108.

Rucht, D., R. Koopmans, and F. Neidhardt, eds. Acts of Dissent. New York: Rowman \& Littlefield, 1999.

Schrodt, Philip A., Shannon G. Davis, and Judy L. Weddle. "Political Science: KEDS - A Program for the Machine Coding of Event Data.” Social Science Computer Review 12, no. 3 (1994): 561-588.

Schrodt, Phillip A. TABARI Textual Analysis by Augmented Replacement Instructions Version 0.8.4 Manual, 2012, available at http://eventdata.psu.edu/tabari.dir/tabari.manual.0.8.4b1.pdf .

Schrodt, Philip A., and Deborah J. Gerner. Analyzing International Event Data (2001/2012). http://eventdata.psu. edu/papers.dir/automated.html.

Schrodt, Philip A., and David Van Brackle. "Automated Coding of Political Event Data" in Handbook of Computational Approaches to Counterterrorism, V.S. Subrahmanian (ed.) 2013, 23-49, Springer Science and Business Media, NY.

Shellman, S. M. "Quantifying Violence and Nonviolence: Terrorism \& Political Violence Events Data Sets." Electronic Newsletter of the ECPR-SG on Extremism \& Democracy 9, no. 2 (2008). Accessed August 19, 2011. http://www.tufts.edu/ dart01/extremismanddemocracy/newsletter/Article7_4.html.

Walker, Joshua. “Learning Strategic Depth: Implications of Turkey’s New Foreign Policy Doctrine.” Insight Turkey 9, no.3 (2007): 32-47.

Y1lmaz, Ömür. "Turkish Military: the Key to Credible Commitment to Democracy." Paper presented at the annual meeting of the International Studies Association, San Diego, California, March 22, 2006. Accessed August 19, 2011. http://www.allacademic.com/meta/p100868_index.html.

Yılmaz, Ömür. "The Kurdish Insurgency in Turkey: Pre- and Post-Ocalan.” Paper presented at the annual meeting of the International Studies Association 48th Annual Convention, Chicago, February 28, 2007. Accessed August 19, 2011. http://www.allacademic.com/meta/p179221_index.html.

Y1lmaz, Ömür. “Turkey Data Set.” Accessed August 19, 2011. http://web.ku.edu/ keds/data.html.

Yonamine, James E. "Working with Event Data: A Guide to Aggregation Choices." Unpublished paper. Accessed 25 April, 2013. http://jayyonamine.com/wp-content/uploads/2012/06/Working-with-Event-Data-A-Guide-toAggregation-Choices.pdf. 